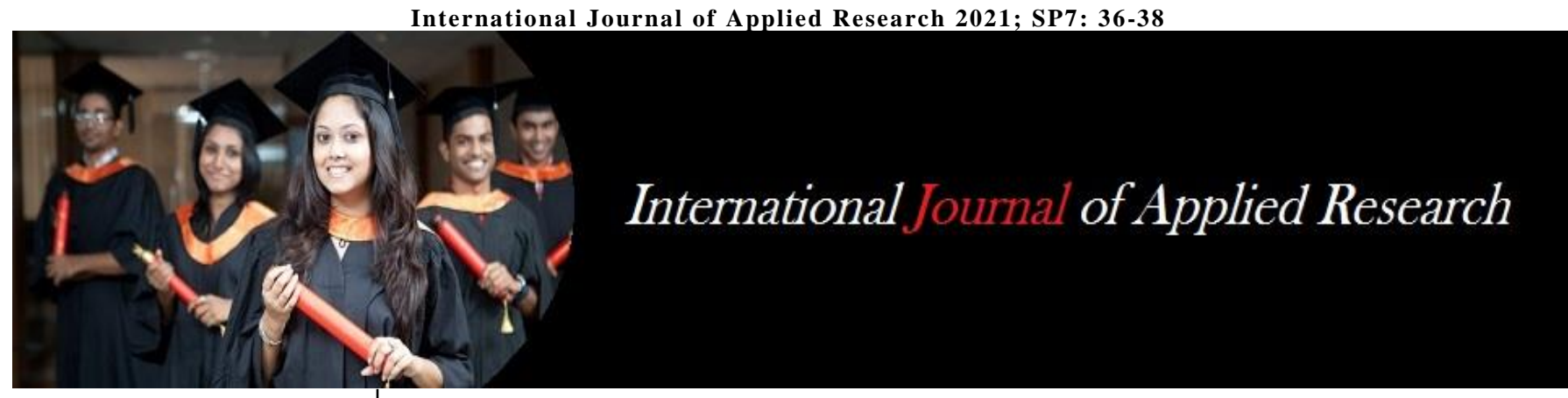

ISSN Print: $2394-7500$

ISSN Online: 2394-5869

Impact Factor: 8.4

IJAR 2021; SP7: 36-38

\section{Ankur Yadav}

Research Scholar, Dr. Bhimrao

Ambedkar University, Agra,

Uttar Pradesh, India

\section{Editors}

\section{Dr. Parmil Kumar}

(Associate Professor),

Sahu Jain (P.G) College,

Najibabad (Bijnor), Uttar

Pradesh, India

\section{Faiyazurrehman}

(Research Scholar),

Dr. Bhimrao Ambedkar

University, Agra), Uttar

Pradesh, India

Dr. Anurag

(Principal),

Baluni Public School

Tallamotadak, Najibabad),

Uttar Pradesh, India

\section{Correspondence}

Ankur Yadav

Research Scholar, Dr. Bhimrao

Ambedkar University, Agra,

Uttar Pradesh, India
(Special Issue)

"Twenty-First Century: Cultural and Economic Globalization"

\section{Postcolonial Consciousness in Kamala Markandaya's A Silence of Desire and Possession}

\section{Ankur Yadav}

DOI: https://doi.org/10.22271/allresearch.2021.v7.i7Sa.8659

Abstract

Postcolonial Studies propels an interdisciplinary and cross-border mode of approaching a text often oscillating backward in times and reverberates the repression, resistance and repudiation of a oncecolonial world. Likewise, in all Postcolonial Literature, Indian Writing in English is also a corollary product of the amalgamation of British Culture and the native Indian Culture. Kamala Markandaya has visaged the corrosion of Indian aesthetic values and erosion of Indian traditional values during the doom of colonization. The paper attempts to study the postcolonial themes in her two novels- $A$ Silence of Desire and Possession. The paper introspects how these two novels depict the palpable conflict between the materialistic approach of the west and traditional ascetic approaches of India and the destructive impact of the same.

Keywords: Postcolonial consciousness, identity, aesthetics, values, resistance

\section{Introduction}

The Postcolonial Studies impels an interdisciplinary and cross-border mode of approaching a text often adhering backward in times and echoing the repression, resistance and repudiation of a once-colonial world. The practices adopted during the colonial time didn't fade away as the imperial power disappeared but continues to exist from that very time to this very time. In fact, Bill Ashcroft in an interesting interpretation states "Postcolonial seems to be the choice which both embraces the historical reality and focuses on the relationship which has provided the most important and creative and psychological impetus in the writing".

Likewise, in all Postcolonial Literature, Indian Writing in English is also a corollary product of the amalgamation of British Culture and the native Indian Culture. The British attempt of spreading the English education has malicious intent of asserting religious and cultural control and to produce a class elucidated in Macaulay's following pronouncement "We must at present do our best to form a class who may be interpreters between us and the millions whom we govern, a class of persons Indian in blood and color but English in tastes, in opinions, in morals and in intellect". The British brought with them the tradition which has materialistic intent, mechanistic approach and temporal attitude to life which was a stern adversary to the Indian tradition whose temporal, anagogic and ascetic approaches went under catastrophic changes under the realm of western influence.

Kamala Markandaya has visaged this corrosion of aesthetic values and erosion of traditional values during the doom of colonization. She has further delved deep into these themes in her two novels-A Silence of Desire and Possession. She shows the palpable conflict between the materialistic approach of the west and traditional ascetic approaches of India and the destructive impact of the same. She presents two similar themes of the encounter between the traditional spiritual values of India and the colonizer values characterized by individualism, scientism and egotism. She further rejects this imposed value 
system of the west which has seeped into our own culture and brought further turbulence in the society.

In A Silence of Desire, there is a conflict between two faiths: the Indian belief of quintessential faith in spiritual powers and the western attitude of pragmatism and unshakable faith in technology or science as the ultimate solution for all our problems. The three main characters of this novel are Dandekar, Sarojini and Swami. Dandekar epitomes the uprooted class of Indian values and assimilates the western philosophy imparted to them by strategic education infused by Britishers. Sarojini embodies the typical Indian women whose adherence to the omnipotence of God is unquestionable. Swami epitomes the spiritual value of Indian society. Both Swami and Dandekar are sketched as the unary opposite of each other and in quest of winning back his wife though psychologically from Swami, Dandekar is pitted against him and what facilitates is an intriguing clash of ideologies. In Markandaya's other novel Possession there is again a confrontation between acquisitive materialism, western belief in civilization and possession and Indian idea of non-possessive spiritualism and the true meaning of life and art. The novel marks an awaited meeting of Indians and British as equals. The novel unfolds with a British divorcee Lady Caroline Bell visiting a village with Anusuya in South India where she discovers a child prodigy and takes her under her possession by giving his parents a sum of 5000. However away from his usual adherence, Valmiki could not flourish his artwork thus a descanted Lady Caroline betrays her spirit by adducing false letters from his guru Swami which rekindles the spirit in him and inspire him to work. Despite being of his mother's age she possesses a sexual desire to possess him. And in the bid of the same, she even plays spoilsport to his love affairs. All this remorse combined with disillusionment caused to him generate his faith in the ascetic and spiritual values of India and he returns back to Swami where he finds the true meaning of life and art.

These novels explore the most dominant theme of postcolonial text i.e. East-West Conflict more specifically Indo British encounter which has excavated deep in roots of contemporary generation, estranged them from their traditional values and brought them into conflict against themself and result from a kind of identity crisis. But the treatment of the subject in Markandaya's novels and the utter rejection of imported western values advocate in order bringing back the contemporary class of people to their own set of aesthetic values.

The theme of East-West conflict crops up in both of her works but more fully and directly in Possession where the embodiment of colonial attitude Lady Caroline Bell thinks that "being British is best" and knowingly or unknowingly wants to stress the fact that India is still in need of England. To the aesthetic values of art in Valmiki, she is in stark contrast on the other side thinking of materialists gains his art could bring her. "He must come away with us now at once. He's wasted here (Possession: 9). Infact the moment when she decided to take him away "There was not even a pause to consider whether he would like to or not; not any recognition of him as a human being" (Possession: 10). Anusuya the narrator of the novel when commenting about the treatment of Valmiki by Caroline further went on to say "Caroline thinks Valmiki belongs to her, and in a way she's right. She won't let go. People don't easily give up what they think are their possessions" (Possession: 198). It would not be wrong to conjecture that her patronage of art governed by the western ideology of materialistic approaches gives way to possession of Valmiki and fails to comprehend his sentiments, the sentiments of a born Indian artist who always tends to be honest with himself as well as to the society. In A Silence of Desire, exposure to western thinking renders Dandekar to understand even his owns wife and his faith in spirituality. Infact the newly imbibed rationalism of Dandekar fails to bridge the gap between the two. The gulf between their ideologies can be perceived by the symbolic Tulsi plant. Dandekar repudiates the faith of Sarojini and her worshipping of Tulsi as 'a plant; one did not worship plants'. The renouncement to western ideology then finds its voice in Sarojini's words when to a question of healing by spiritual powers of Swami she asserts, "Yes, you can call it healing by faith, or healing by the grace of God if you understand what that means. But I do not expect you to understand you with your western notions, your superior talks of ignorance and superstition when all it means is that you don't know what lies beyond reason and you prefer not to find out. To you the Tulsi is a plant that grows in the earth like the rest an ordinary common plant. And mine is a disease to be cured and so you would have sent me to hospital and I have died there" (A Silence of Desire: 87-88).

Dandekar and Valmiki are both the product of Western Education as asserted by Macaulay and marred by their own set of traditional values Dandekar hinges back and forth between his newly imbibed rationally and distrust in need of transcendence in life. Whereas in Possession Caroline grows in pride by telling Anusuya about the upbringing of Valmiki "grown completely away from it all-he'll never be able to be to settle down with his people again" (Possession: 104). It is their this detached self that gives way to a fair amount of turbulence in their life. As stated it is Dandekar's rationalism that impedes him to understand his wife's psychology to any level of gratification. His impediment is further adduced by the learning of fact that his wife goes to Swami for the ailments and healing of her problems. To a western educated mind, this figure of Swami and his notion of spiritual healing should have died somewhere in the medieval ages. At first, he didn't even want to bear the sight of that 'trickster'. He feels that he is a trickster or a clever monkey who is putting words into his mouth. But the mere sight of Swami dispels any such idea. He feels like his spirituality is overpowering him and in his realms, he feels that Swami is taking out words from his mouth so he stopped himself to put up any personal questions. During his visit to the village where Swami sometimes lives he didn't find any opulence and grandeur around him or in the place, he used to reside. Contrary to this what he discovers is a magnanimous Swami and his altruistic nature who gives away what all he takes. The figure of Swami breaks the stereotypical notion of western ideas of money, knowledge, selfhood, work ethic and faith. Swami breaks the conception of the west that one should not be idle and has to do something always in contrast to this Swami sits placidly and echoes that the self which is to be realized is not the object of an act. The figurine of Swami is again challenged in Possession although to a lesser extent when realized the truth about crude behavior and malign intent of Caroline, Valmiki returns back to Swami. A dejected Caroline musters up enough courage to face Swami in his last attempt 
to win back Valmiki. However, like Dandekar she too feels kind of lacerated by his spirituality. She went there to reclaim Valmiki but couldn't raise herself even to realize what Swami imparts. Swami isn't interested in money he just takes little which is needed and the rest he gives away while Caroline is an epitome of materialistic approaches who even went on to exploit Valmiki for her own monetary gains. Swami possesses a non-acquisitive attitude and doesn't have any intention to control Valmiki, unlike Caroline who even wants to possess the soul of Valmiki. S.C. Harrex finds Markandaya's works deal with "different predicaments of identit ...... each .......affected by the EastWest clash of codes that is part of modern India". Both Valmiki and Dandekar went through this purgatory period before finding their content and attaining their true self through the spiritual values and divine presence of Swami. Swami is the representative of the soul of India, an emblem of traditional and aesthetic values of India. In both the novels Swami gives shelter to destitute and derelicts (Sarojini in A Silence of Desire and Valmiki in Possession). $\mathrm{He}$ is not to be considered a "misfit edged by his fellowmen" but one who has voluntarily come out and has chosen a path to find inner peace. The mere presence of Swami is a panacea for anyone who comes to him. It is doubtful whether Sarojini who recuperates well at the end of A Silence of Desire would have survived. He imparts spiritual strength to Sarojini for undergoing surgery and he also gifted her a will to live without which she couldn't have survived.

The departure of Swami instills Dandekar with remorse and guilt and overcomes whatever sense of joy, happiness and pride he would have had after he has forced Swami to leave the town. Swami has psychologically thrashed the western cultivation in Dandekar's mind. His notions about being rich are shattered by Swami's idea "one isn't rich until one has nothing left to give away". The 'Dwarf' to whom Dandekar gives money symbolizes the crippled ness of him and his belittlement before the enlarged, universal, spiritual image. Swami gives away all the money he gets for the proliferation of the poor and deprived. After Swami had left Dandekar involuntarily goes to the place where Swami lived, there he further sinks into a sea of remorse after seeing the deterioration of place and the derelicts. Furthermore, the image of the Banyan tree in the culminating section of the novel allegorizes a dejected Dandekar who could hardly move and walk, his legs are like water reeds tied to the ground to hinder his movement. Swami also kindled " a spiritual in growing which made it possible for him to be whole so long as any part of her was missing" (A Silence of Desire: 191). This changed perspective of Dandekar is then depicted by the image of a turbulent night storm followed by a gentle breeze in the morning. This psychological defeat of Dandekar is a vindication of Swami's ever-enduring values. It is not only his personal defeat but the defeat of an imported modern and acquisitive society. In Possession too, Valmiki returns back to sacred caves and sagacious Swami to get back his lost identity. The West gave him a sense of temporal ephemerality but only at the expense of a tumultuous soul always contemplating about his lost spirit. The West may have been able to transform him for a period of time but failed to convert him. Valmiki has achieved materialistic ascendance with Caroline and a sense of emptiness with Swami only to realize later that this emptiness is the materialistic ascendance he craves for and is in abundance with Swami. He finds the ultimate meaning of his art by dedicating it to the divine. In the last pages of the novel, Caroline fails to praise the artwork done by Valmiki to which Swami asserts ".... There is also divine spirit.... He works for that, and this is the glory" (Possession: 232). The crippling western impact fades away in the last and Valmiki's flickering faith rekindles in the spiritual aura of Swami. When Caroline reminds Valmiki of the awful "wilderness" of India, Valmiki remarks "no crime the wilderness is mine, it is no longer terrible as it used to be..... it is nothing" (Possession:231). Swami aided Valmiki with his reply "even this wasteland may have something to show other than what you have seen" (Possession: 231). The term 'wasteland' is very symbolic not only in the context of the novel but in terms of colonial consciousness as these words not only refute the western notion that India is inferior but also jolts the ideology that India seeks help from them. India and its value are enough robust in itself that they don't partake any help from anyone to survive. Both the novels have Swami as an ascetic figure of quintessential India Culture. In the end, it is their spiritual values that triumph over the mundane represented by stubborn West.

The imported modern consciousness as it has manifested itself is a pointer to its up rootedness in the contemporary Indian reality of that time. The complexities and pressure of the so-called modern living resist simplistic stances and facile value judgments. Hence identity crisis and skepticism towards own set of traditional values become an undesirable impediment. These two novels of Kamala Markandaya show the destructive impact of colonization caused by the imposition of the western culture and their way of life which she lucidly rejects and patronizes a return to our own tradition and culture by asserting it as a wasteland which has lot more to offer!

\section{References}

1. Ashcroft Bill, Gareth Griffiths, Hallen Tiffin. The Empire Writes Back: Theory and Practice in PostColonial Literatures. London: Routledge 1989.

2. Aithal SK. Indo-British Encounter in Kamala Markandaya's Novel. Post-Colonial Indian English Writing. Ed. R.A. Singh and Sanjay Kumar. New Delhi: Bahri Publications 1997.

3. Harrex SC. A Sense of Identity: The Novels of Kamala Markandaya. Journal of Commonwealth Literature 1971;6(1):65-78.

4. Nayak PM, Sadanad Mishra. Colonial Consciousness in Markandaya's A Silence of Desire and Possession. PostColonial Indian English Writing. Ed. Singh RA and Sanjay Kumar. New Delhi: Bahri Publications, 1997.

5. Markandaya Kamala. A Silence of Desire. New Delhi: Sagar Publications, 1968.

6. Markandaya, Kamala. Possession. Bombay: Jaico Publishing House, 1963.

7. Mishra, N.K. "Taming of the crude: A Study of Kamala Markandaya's Possession". Kamala Markandaya: A Critical Spectrum. Ed. Manmohan Krishna Bhatnagar. New Delhi: Atlantic, 2002.

8. Macaulay, Thomas. "Minute on Indian Education". The Speaking tree. Ed. Richard Lannnoy. London: Oxford University Press, 1971

9. Rajeshwar M. The Unconscious Desire and its fulfillment in Kamala Markanadaya's A Silence of Desire. Kamala Markandaya: A Critical Spectrum. Ed. Manmohan Krishna Bhatnagar. New Delhi: Atlantic 2002. 